\title{
Slow photons for solar fuels
}

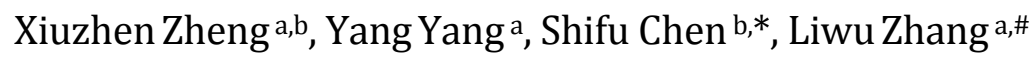 \\ a Shanghai Key Laboratory of Atmospheric Particle Pollution and Prevention, Department of Environmental Science and Engineering, Fudan University, \\ Shanghai 200433, China \\ b College of Chemistry and Material Science, Huaibei Normal University, Huaibei 235000, Anhui, China
}

\section{A R T I C L E I N F O}

\section{Article history:}

Received 1 August 2017

Accepted 14 September 2017

Published 5 March 2018

\section{Keywords:}

Photonic crystal

Slow photons

Inverse opal

Water splitting

Photocatalytic $\mathrm{H}_{2}$ production

$\mathrm{CO}_{2}$ photoreduction

\begin{abstract}
A B S T R A C T
Converting solar energy into hydrogen and hydrocarbon fuels through photocatalytic $\mathrm{H}_{2}$ production and $\mathrm{CO}_{2}$ photoreduction is a highly promising approach to address growing demand for clean and renewable energy resources. However, solar-to-fuel conversion efficiencies of current photocatalysts are not sufficient to meet commercial requirements. The narrow window of solar energy that can be used has been identified as a key reason behind such low photocatalytic reaction efficiencies. The use of photonic crystals, formed from multiple material components, has been demonstrated to be an effective way of improving light harvesting. Within these nanostructures, the slow-photon effect, a manifestation of light-propagation control, considerably enhances the interaction between light and the semiconductor components. This article reviews recent developments in the applications of photonic crystals to photocatalytic $\mathrm{H}_{2}$ production and $\mathrm{CO}_{2}$ reduction based on slow photons. These advances show great promise for improving light harvesting in solar-energy conversion technologies.
\end{abstract}

(C) 2018, Dalian Institute of Chemical Physics, Chinese Academy of Sciences. Published by Elsevier B.V. All rights reserved.

\section{Introduction}

Human civilization is powered mainly by fossil fuels such as oil, coal, and natural gas. However, the combustion of these fuels causes environmental pollution and considerable $\mathrm{CO}_{2}$ emissions. Solar power is widely recognized as a promising alternative to fossil-fuel-based energy sources. Considerable efforts have been made in the study, design, and synthesis of novel materials that can convert solar energy into heat, electricity, and chemical energy [1-4]. One such strategy is photocatalytic splitting of water molecules to generate hydrogen or to drive the reduction of $\mathrm{CO}_{2}$ into valuable hydrocarbon fuels [5-8]. Currently, a myriad of materials has been shown to be potential candidates for such photocatalytic reactions. Howev- er, owing to limited light absorption and high rates of charge carrier recombination, the conversion efficiencies of current photocatalysts remain too low to meet commercial requirements. To enhance light harvesting, one important approach is to improve the interaction of light with the semiconductor, by manipulating light propagation in the various material structures. For instance, multiple scattering can be used to induce more photons to be absorbed under given incident light conditions $[9,10]$. Random scattering by large particles [11] or spherical voids [12] has also been applied in dye-sensitized solar cells. Furthermore, hierarchically structured porous materials provide interconnected porosity at different length scales, which is favorable for light harvesting [13-15]. Photonic crystals are formed by specific periodic arrangements of die-

\footnotetext{
* Corresponding author. E-mail: chshifu@chnu.edu.cn

\# Corresponding author. E-mail: zhanglw@fudan.edu.cn

This work was supported by the National Natural Science Foundation of China (21607027, 21507011 and 21677037), and Ministry of Science and Technology of the People's Republic of China (2016YFE0112200).

DOI: 10.1016/S1872-2067(17)62930-9 | http://www.sciencedirect.com/science/journal/18722067 | Chin. J. Catal., Vol. 39, No. 3, March 2018
} 
lectric materials, which have a unique role in regulating light, through light reflection, scattering, and the slow photon effect. The phenomena allow control over light propagation in the medium structure.

Photonic crystals are the best materials devised for light manipulation. Several papers have reviewed photochemical applications of photonic crystals, focused mainly on photocatalysis [14,16-18] and photovoltaics [14,17]. The slow photon effect has also been reviewed from the viewpoint of photocatalytic degradation $[14,16]$. In this review, we discuss both theoretically and experimentally the importance of the slow-photon effect in light-harvesting enhancement and its applications in solar-to-fuel energy conversion, i.e., photocatalytic $\mathrm{H}_{2}$ production and $\mathrm{CO}_{2}$ photoreduction. The photoreactivity enhancement of slow photons is highlighted and we discuss the potential for making considerable improvements to light harvesting through several strategies, which are likely to attract attention in the near future.

\section{Photonic crystals and slow photons}

Photonic crystals are periodic ordered structures in space composed of two or more materials with different dielectric constants. When light propagates inside a photonic crystal, the periodic Bragg scattering modulates light to form a photonic band gap (PBG), which is analogous to the electronic bandgap in semiconductor materials. In photonic crystals, light with certain frequencies is forbidden from propagating owing to the photonic stop band arising from the periodic modulation of the refractive index $[19,20]$. Slow light propagation near this stop band is a unique property of photonic crystals, and is an important principle for enhancing solar energy conversion efficiency $[17,21,22]$. As illustrated in Fig. 1, at the lower photon energy edge (red edge) of the photonic bandgap, the light standing wave peaks are primarily localized in the high refractive index sections of the photonic crystal, whereas at the higher photon energy edge (blue edge), the standing wave peaks are localized in the low refractive index sections [23]. This mechanism provides photonic crystals with the ability to manipulate light in a unique manner. Most importantly, at both the blue and red edges of the photonic bandgap, vanishing group velocity is observed. Photons with reduced group velocity are termed "slow photons" or "slow light" [14,23].

The slow-photon effect has been demonstrated, both theoretically and experimentally to be a promising solution for increasing light absorption in semiconductors by extending the residence time of photons in the material. When the electronic bandgap of the material and either the red edge or the blue edge of the photonic bandgap of the structure overlap in the frequency (wavelength) domain, slow photons are expected to improve light harvesting. Irradiation at a photon energy related to the structured material means that slow photons on the edges of the photonic bandgap ensure a longer presence of that energy within the structure, and the electronic bandgap allows the photon energy to be transferred to electrons and holes [14]. Coordination of these three phenomena is essential to extracting the benefits of slow photons for solar energy harvesting, e.g.

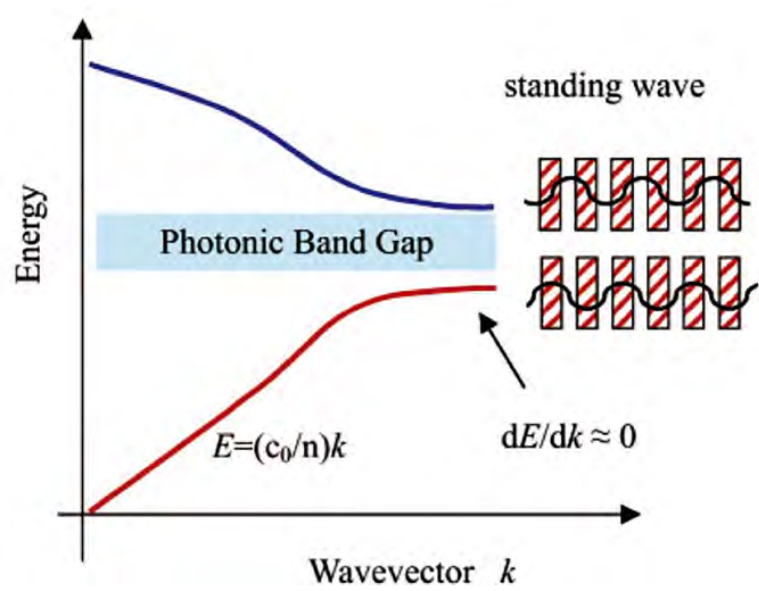

Fig. 1. Simplified photonic band structure of a photonic crystal. Near the Brillouin zone center, light travels with velocity $c_{0} / n$, where $c_{0}$ is the speed of light in a vacuum, and $n$ is the average refractive index. At photon energies approaching the full bandgap or a stop band from the red side, the group velocity of light decreases and light can be increasingly described as a sinusoidal standing wave that has its highest amplitude in the high refractive index part of the structure. At energies above the bandgap or stop band, the standing wave is predominantly localized in the low refractive index part of the photonic crystal, i.e., in the air voids. Reproduced with permission [23]. (Copyright 2003 American Chemical Society Publishing Group).

photocatalytic degradation [18,24-27] and solar cells [23,28-30]. There are also conventional uses in lasers [31-34] and some other optical applications [35-39]. In the following sections, we survey the properties of photonic crystal materials and give examples of their applications to solar-to-fuel conversion based on slow photons (mainly photocatalytic $\mathrm{H}_{2}$ production and $\mathrm{CO}_{2}$ photoreduction).

\section{Solar-to- $\mathrm{H}_{2}$ energy conversion}

Energy and environmental problems are well-known currently issues. Hydrogen fuel is a clean energy source that could provide the ultimate solution to many pollution problems. In particular, hydrogen evolution from water splitting powered by renewable solar energy represents a promising but challenging method to a clean, sustainable and affordable energy system. In this review, photocatalysts are structured into photonic crystal architectures to maximize the usage and conversion of light energy. Photonic crystal segments show a great capacity for light harvesting owing to the slow photon enhancement at the stop band edge and multiple scatterings among the segments.

Since the pioneering work of Fujishima and Honda in 1972, photocatalytic water splitting to produce $\mathrm{H}_{2}$ using solar energy as the driving force has drawn considerable attention $[5,8]$. Generally, there are two configurations of photoconversion systems for water splitting. The first configuration of the photocatalytic system involves a suspension of the photonic crystal particles in a solvent $[40,41]$. This kind of system is made up of simple devices and accessible photocatalysts, where the driving force for water splitting comes entirely from solar energy. The reduction and oxidation reactions occur at different surface 
sites of the same photocatalyst particles, and some sacrificial agents $\left(\mathrm{Na}_{2} \mathrm{~S}\right.$ and $\mathrm{Na}_{2} \mathrm{SO}_{3}$ [41], methanol [42] and triethanolamine [43]) are used to improve the $\mathrm{H}_{2}$ production. The other configuration is known as the photoelectrochemical (PEC) system, composed of a photonic crystal photoelectrode (working electrode), a counter electrode and usually a reference electrode. The photoelectrode harvests light to generate charge carriers and performs the oxidation reaction, often at the photoanode to produce $\mathrm{O}_{2}$, whereas the reduction reaction takes place at a counter electrode to produce $\mathrm{H}_{2}$. Compared with photocatalytic systems, PEC systems may achieve higher efficiency because an external bias can be applied to promote the separation of photogenerated electrons and holes [44-51]. Therefore, it is beneficial to perform $\mathrm{H}_{2}$ production with the use of PEC systems although the preparation of the photoelectrodes is complicated and normally an external bias is needed.

\subsection{Photocatalytic water splitting}

The inverse opal (IO) structure is a kind of photonic crystal, which features an ordered arrangement of pores and has attracted considerable attention owing to the effect of this structure on light harvesting. A typical example is $\mathrm{TiO}_{2}$ inverse opal, which has been studied extensively for improving the efficiency of photocatalytic processes $[16,52]$. $\mathrm{TiO}_{2}$ inverse opals can considerably increase the photocatalytic performance of $\mathrm{TiO}_{2}$ owing to the slow light phenomenon, which improves light-matter interactions by reducing the group velocity of light at the PBG edges [53-55]. Therefore, the $\mathrm{TiO}_{2}$ inverse-opal structure can promote light absorption of $\mathrm{TiO}_{2}$, leading to more photogenerated electron-hole pairs and a high hydrogen evolution. To test the presence of a synergic effect between slow light and faster electron transfer, Sordello et al. have compared the activity of Pt-loaded $\mathrm{TiO}_{2}$ inverse opals and of Pt-loaded macroporous disordered $\mathrm{TiO}_{2}$ structures in hydrogen photoproduction experiments [40]. To discriminate the effects of slow photons, the hydrogen photoproduction experiments were performed at two different wavelengths, at $365 \mathrm{~nm}$, where the effects of slow photons are maximized, and at $254 \mathrm{~nm}$ where the effects are negligible. Upon irradiation at $365 \mathrm{~nm}$, the synthesized $\mathrm{TiO}_{2}$ inverse opals showed a higher hydrogen production rate than that of the disordered macroporous structures without an ordered arrangement of pores, owing to the slow light phenomenon.

Liu et al. [42] demonstrated that the hierarchical inverse-opal $\mathrm{Pt}-\mathrm{TiO}_{2}$ photonic crystal segments could provide effective light harvesting and improve hydrogen evolution. In this work, $\mathrm{TiO}_{2}$ materials were designed and structured into hierarchical photonic crystal segments with stop bands overlapping with the absorption of $\mathrm{TiO}_{2}$. A series of $\mathrm{TiO}_{2}$ photonic crystal films modified with Pt nanoparticles (NPs) with stop bands ranging from 307 to $434 \mathrm{~nm}$ were investigated in photocatalytic hydrogen generation experiments. The largest enhancement factors (EFs) under white light illumination occurred for photonic crystal films with stop bands of $307 \mathrm{~nm}$ (EF $=2.4)$ and $342 \mathrm{~nm}(\mathrm{EF}=2.5)$ relative to nanocrystalline $\mathrm{TiO}_{2}$. The enhancement of photocatalytic activity was attributed to the slow photon enhancement at the stop band edge and multiple scatterings among the photonic crystal segments.

Waterhouse et al. [56] prepared $\mathrm{Au} / \mathrm{TiO}_{2}$ inverse-opal photocatalysts, which exhibited remarkable photocatalytic activity and stability for photocatalytic water splitting under UV and sunlight. The optical (PBG position) and electronic $\left(\mathrm{TiO}_{2}\right.$ absorption edge) properties of the $\mathrm{TiO}_{2}$ inverse opal support coincided to enhance the slow photon effect and suppress electron-hole pair recombination in $\mathrm{TiO}_{2}$. Thus, the photocatalytic activity of the $\mathrm{Au} / \mathrm{TiO}_{2}$ photocatalysts for $\mathrm{H}_{2}$ production from water was improved. The supported gold NPs acted as sites for $\mathrm{H}_{2}$ production, which might allow for visible light excitation of $\mathrm{Au} / \mathrm{TiO}_{2}$ photocatalysts via the gold surface plasmon.

In addition to $\mathrm{TiO}_{2}$, CdS is also regarded as a promising material for water splitting. However, the relatively low PEC response and poor stability of CdS have restricted its practical applications. The propagation of light in photonic materials can be modified to increase the probability of photon absorption. Mitchell et al. reported the synthesis of composite materials comprising a photochemically inert photonic macroporous $\mathrm{ZrO}_{2}$ support decorated with photocatalytically active CdS NPs [57]. The relative energies of the valence and conduction bands restricted photon absorption and catalysis of the CdS NPs. The generation of hydrogen from water under visible light illumination ( $>400 \mathrm{~nm}$ ) was studied for different photonic supports. A maximum 4.7-fold enhancement in hydrogen production was observed compared with that of a non-photonic support when the absorption band of the CdS NPs partially overlapped with the blue edge of the photonic $\mathrm{ZrO}_{2}$ stop band. The photochemical activity of the NPs could be modified within a chemically inert photonic host to increase the yield of hydrogen production under broad band illumination. These data were consistent with increased photon absorption owing to the 'slow photon' effect induced by the photonic host. In these systems, the enhancement was maximized when the blue edge of the stop band overlapped with the onset of the photocatalyst absorption. This general strategy involves independent optimization of optical and photochemical processes to increase the overall conversion efficiency from solar to chemical energy.

Cui et al. successfully fabricated a photonic crystal-based $\mathrm{CdS}-\mathrm{Au}-\mathrm{WO}_{3}$ heterostructure by orderly depositing $\mathrm{Au}$ and $\mathrm{CdS}$ onto the framework of structured $\mathrm{WO}_{3}$ inverse-opal photonic crystal segments. [41] Their system showed superior activity toward photocatalytic water splitting for both hydrogen and oxygen evolution under visible light illumination. The excellent performance was attributed to the synergistic integration of good light harvesting of slow photons and efficient electron transfer within the heterostructure.

Graphitic carbon nitride $\left(\mathrm{g}-\mathrm{C}_{3} \mathrm{~N}_{4}\right)$ has attracted considerable attention in photocatalysis owing to its extraordinary features, such as good thermal and chemical stability, metal-free composition, and easy preparation. Sun et al. have obtained freestanding macroscopic g- $\mathrm{C}_{3} \mathrm{~N}_{4}$ photonic crystals by highly ordered, crack-free colloidal crystal templating [43]. Their g- $\mathrm{C}_{3} \mathrm{~N}_{4}$ photonic crystals exhibited enhanced photodegradation and hydrogen evolution activity under visible light irradiation. The enhancement was attributed to the combination of slow photon 
effects, multiple scattering, the hierarchical porous structure, and a low rate of radiative recombination. The hydrogen evolution rate of $1979 \mu \mathrm{mol} / \mathrm{g} \cdot \mathrm{h}$ under $\lambda>420 \mathrm{~nm}$ irradiation was 8.82 times as high as that of bulk g- $\mathrm{C}_{3} \mathrm{~N}_{4}$.

\subsection{Photoelectrocatalytic water splitting}

The ordered 2D structure of nanotube (NT) arrays confers photonic crystalline properties owing to the periodic modulation of the dielectric constant [58-60]. There are three advantages to the use of $\mathrm{TiO}_{2}$ NTs that can be achieved from a photonic band structure: (1) the PBG can be used to confine incident light of a proper wavelength within the $\mathrm{TiO}_{2}$ NT film, (2) the dielectric band can be used to concentrate the incident photons of the corresponding wavelength on the $\mathrm{TiO}_{2} \mathrm{NT}$ walls, and (3) the absorption efficiency of these photons is further boosted by their reduced group velocity (slow photons) owing to flattening of the photonic band in certain propagation directions. Chiarello et al. demonstrated that photonic crystals could be used to increase the efficiency of solar light harvesting and conversion and the photocatalytic performance on $\mathrm{TiO}_{2}$ NT array-based photoanodes [61]. Further performance improvements could be attained by tilting the incident light angle, thus increasing the fraction of photons scattered parallel to the film, which can sense the photonic crystal properties. Theoretical calculations have demonstrated that the position and width of the PBG are both affected by the $\mathrm{TiO}_{2}$ NT inner diameter, wall thickness, and the distance between the pores. Thus, the PBG could be easily tuned by adjusting the $\mathrm{TiO}_{2}$ NT synthesis parameters to match with the semiconductor absorption band, with the aim of red-shifting the photoactivity threshold. In this way, a $50 \%$ higher $\mathrm{H}_{2}$ production rate under polychromatic irradiation can be attained by simply increasing the inner $\mathrm{TiO}_{2}$ NT diameter. This important result can in principle be transferred to any other semiconductor material and is useful in the field of solar fuel production for harvesting and converting a wide range of the solar spectrum.

The fabrication of novel photocatalysts faces challenges in attempting to satisfy the demand for wide visible light response and high quantum efficiency. In terms of photonic crystals, the exploration of new photocatalysts is key to making a breakthrough in photocatalysis. Some oxide semiconductors with relatively narrow band gaps, for example, $\mathrm{WO}_{3}$ (band gap, $E_{\mathrm{g}}=$ 2.6-2.8 eV), have attracted attention as photoanode materials because of their visible light response and good photochemical stability. Chen et al. demonstrated that photonic crystals could be used to improve PEC performance under visible light irradiation [62]. Inverse opal $\mathrm{WO}_{3}$ photoanodes with different stop-bands have also been prepared (Fig. 2). Considerable enhancement of the photocurrent intensity was achieved at an inverse opal photoanode by adjusting the wavelengths of the slow light to be closer to the electronic absorption edge of $\mathrm{WO}_{3}$. The light harvesting and photon-to-electron conversion efficiency at specific wavelengths was remarkably enhanced due to the slow-light effect in inverse opals. The spectral range at which photon-to-electron conversion efficiency was enhanced moved to shorter wavelengths as the incident angle increased, which resulted from a blue-shift in the stop-band center.

Zhang et al. [63] reported the design and fabrication of 3D $\mathrm{WO}_{3} / \mathrm{BiVO}_{4} /$ cobalt phosphate (Co-Pi) composite inverse opal electrodes for PEC water splitting by electrodeposition of a $\mathrm{BiVO}_{4}$ layer and a Co-Pi water oxidation catalyst on the $\mathrm{WO}_{3}$
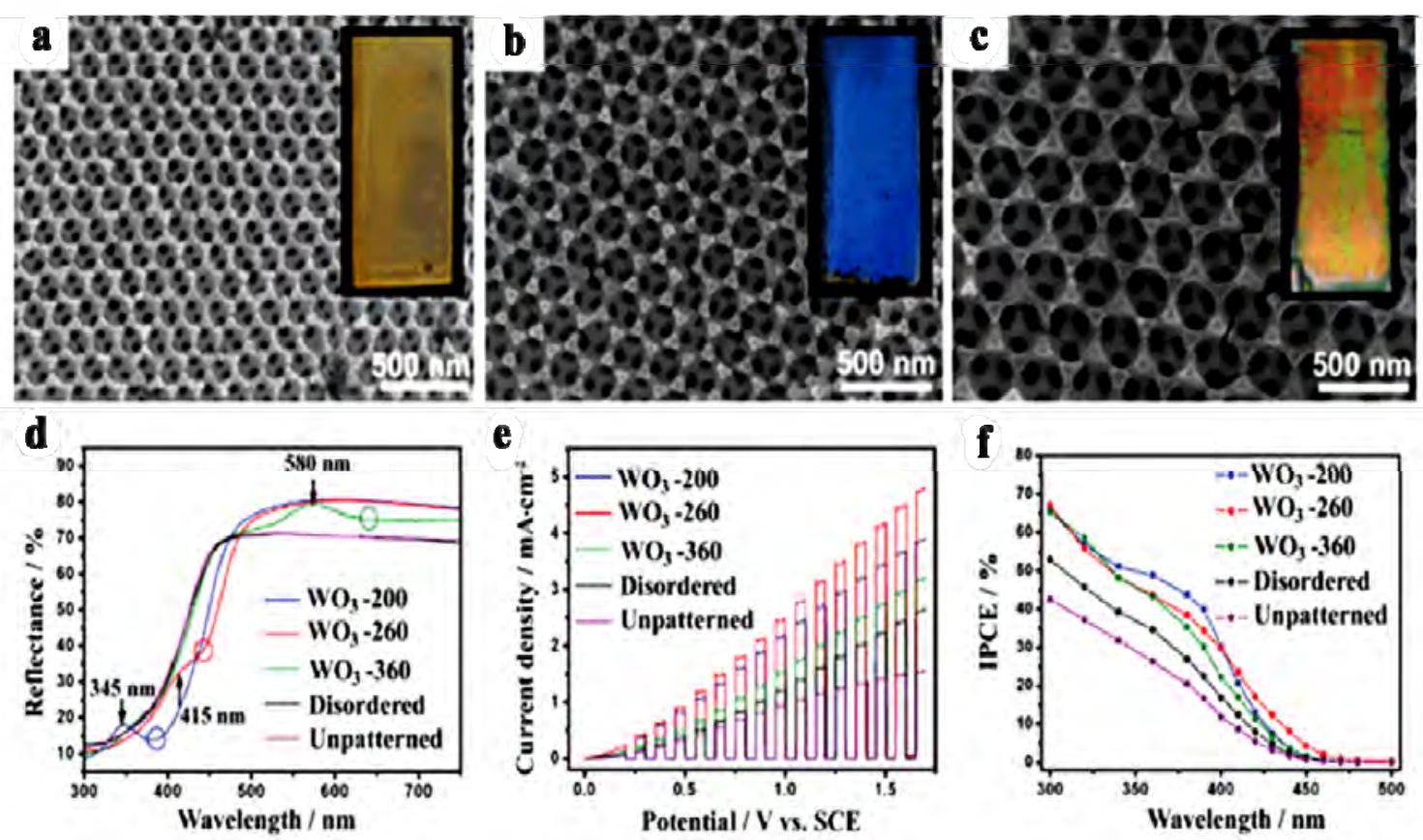

Fig. 2. (a-c) SEM images of $\mathrm{WO}_{3}$ inverse opals with diameters of 200, 260, and $360 \mathrm{~nm}$, respectively. (d) Light reflectance spectra of the WO $\mathrm{W}_{3}$ inverse opals. (e) Photocurrent-potential curves of $\mathrm{WO}_{3}$ electrodes under light irradiation at $300 \mathrm{~nm}$. (f) Incident photon-to-electron conversion efficiency. Reproduced with permission [62]. (Copyright 2011 American Chemical Society Publishing Group). 
inverse opal. In this novel electrode design, the continuous and conductive $\mathrm{WO}_{3}$ inverse opals acted as host skeletons for the deposition of a $\mathrm{BiVO}_{4}$ layer, which provided direct and fast electron transport pathways. The void spaces of the inverse opals were advantageous for the $\mathrm{BiVO}_{4}$ layer filling, which facilitated excellent interfacial contact with a large surface area. The "slow photon effect" of the inverse opals provides additional benefits for light harvesting. Moreover, the surface decoration of the water oxidation catalyst was beneficial for improving the water oxidation kinetics of $\mathrm{BiVO}_{4}$. Thus, the as-fabricated $\mathrm{WO}_{3} / \mathrm{BiVO}_{4} / \mathrm{Co}-\mathrm{Pi}$ photoanode presented excellent PEC performance and achieved a maximum photocurrent density of 4.5 $\mathrm{mA} / \mathrm{cm}^{2}$ at $1.4 \mathrm{~V}$ versus $\mathrm{Ag} / \mathrm{AgCl}$, which was much better than that of the individual constitutes, i.e., $\mathrm{WO}_{3}$ and $\mathrm{BiVO}_{4}$.

Additionally, other photonic crystals have also been used to improve solar conversion efficiency, such as $\mathrm{BiWO}_{4}$. Zhang et al. developed a facile and economical method to synthesize $\mathrm{Bi}_{2} \mathrm{WO}_{6}$ inverse-opal photonic-crystal structures, as an example of visible-light active ternary metal oxides [64]. $\mathrm{Bi}_{2} \mathrm{WO}_{6}$ inverse opals $\left(\mathrm{i}-\mathrm{Bi}_{2} \mathrm{WO}_{6}\right)$ exhibited much higher photocatalytic activities for degradation of methylene blue and salicylic acid, respectively, under visible light illumination compared with the performance of a reference $\mathrm{Bi}_{2} \mathrm{WO}_{6}$ nanofilm $\left(n-\mathrm{Bi}_{2} \mathrm{WO}_{6}\right)$. A slow photon effect was observed in the angle dependent photodegradation of methylene blue under visible-light irradiation. The photon-to-hydrogen conversion efficiencies of PEC water splitting under visible-light irradiation exhibited an almost three-fold increase owing to the inverse-opal structure. Such enhancements in the photocatalytic activity and photoelectro- chemical $\mathrm{H}_{2}$ production activity were related to improved light-harvesting properties and the continuous porous structure of the inverse-opal structure.

In photonic crystals, there are two ways of enhancing the slow photon effect: one is to tune the photonic crystal stop band around the semiconductor band edge (as described above); the other is to tune the photonic crystal stop band around the excitation maxima of sensitizers such as plasmonic metal NPs, and quantum dots (QDs). In the field of PEC water splitting, plasmonic metals are becoming a material of choice for photoactive materials to boost efficiency in this process (i.e., to enable processes to occurs at very low voltages). These materials are highly stable and provide tunability in light matter interactions that are useful for absorption, activity, catalysis, and efficiency. Properties being assessed for PEC systems include: surface plasmon resonance (SPR) of metal NPs, absorption at the band edge of supporting semiconducting materials, angle dependence or enhanced light capture with the use of PBG materials in energy regions where the absorption of a material itself is poor, plasmon-photon coupling scenarios, and tuning of the slow photon effect to match the SPR resonances and thus charge injection, are all. We detail some of these advances in the references cited below.

Zhang et al. [65] designed a visible light responsive plasmonic photocatalytic composite material by rationally selecting Au nanocrystals and assembling them on $\mathrm{TiO}_{2}$-based photonic crystal substrate. Plasmonic Au nanocrystals coupled with $\mathrm{TiO}_{2}$ NTs with a top seamless photonic crystal layer showed excellent PEC water-splitting performance (Fig. 3). The matching of
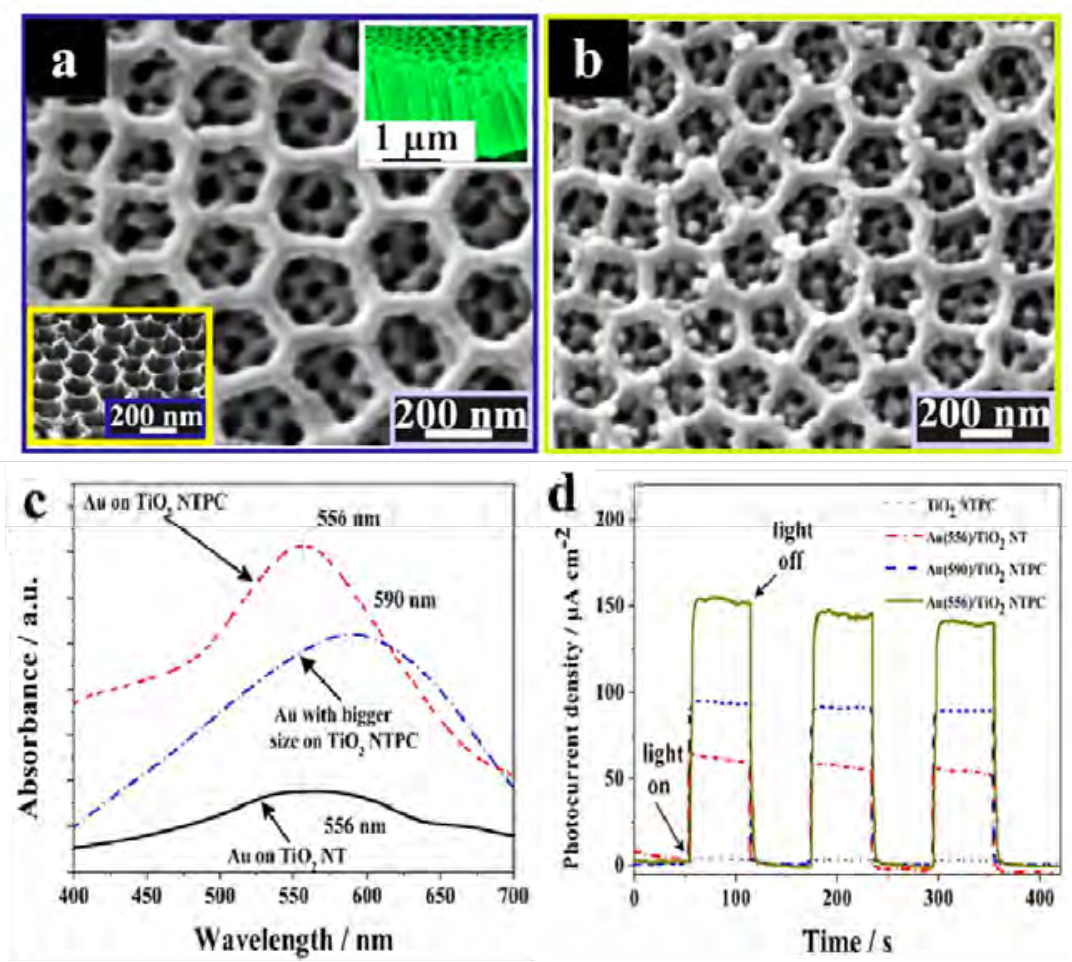

Fig. 3. SEM images of (a) $\mathrm{TiO}_{2} \mathrm{NT}$-photonic crystal and (b) $\mathrm{Au} / \mathrm{TiO}_{2} \mathrm{NT}$-photonic crystal; (c) SPR absorption spectra of the Au nanocrystals on the TiO 2 NT-photonic crystal and $\mathrm{TiO}_{2} \mathrm{NT}$, with the spectrum of $\mathrm{TiO}_{2}$ being subtracted; (d) Amperometric $I-t$ curves of the TiO 2 NT-photonic crystal and Au (556) $/ \mathrm{TiO}_{2}$ NT-photonic crystal at an applied potential of $1.23 \mathrm{~V}$ vs. RHE under visible light illumination. Reproduced with permission [65]. (Copyright 2013 American Chemical Society Publishing Group). 
the Au SPR wavelength with the photonic crystal photonic band gap considerably increased the SPR intensity and thus boosted the PEC performance. Under visible light illumination $(>420$ $\mathrm{nm}$ ), the designed material produced a photocurrent density of $\sim 150 \mu \mathrm{A} / \mathrm{cm}^{2}$, which is the highest value reported for any plasmonic $\mathrm{Au} / \mathrm{TiO}_{2}$ system under visible light irradiation owing to photonic crystal-assisted SPR. The rational design of the plasmonic-photonic crystal systems opens a new avenue of research into preparation of efficient visible light photocatalysts.

Zhang et al. [66] designed a series of $\mathrm{Au} / \mathrm{TiO}_{2}$ composite photoanodes by constructing two promising $\mathrm{TiO}_{2}$ functional structures (i.e., nanorod arrays and photonic crystals) as scaffolds for Au NPs (Fig. 4). The enhanced PEC water splitting activity under visible light irradiation was attributed to energetic hot electrons and holes that were generated in the Au NPs through the excitation and decay of surface plasmons. By alternating the characteristic pore size of the $\mathrm{TiO}_{2}$ photonic crystal layer, the slow photon region at the red edge of the photonic band gap could be tuned to overlap with the strong localized SPR region of the Au NPs. The matched slow photon effect of the $\mathrm{TiO}_{2}$ photonic crystal (with a characteristic pore size of 250 $\mathrm{nm}$ ) intensified the SPR responses (central at $536 \mathrm{~nm}$ ) of the $\mathrm{Au}$ NPs. Consequently, more hot electrons were generated in the $\mathrm{Au}$ NPs and injected into the conduction band of the $\mathrm{TiO}_{2}$, resulting in improved PEC water splitting efficiency in the visible light region. Under simulated sunlight illumination, the photoconversion efficiency of the well matching $\mathrm{Au} / \mathrm{TiO}_{2}$ photoanode approached $0.71 \%$, which is among the highest values reported for $\mathrm{Au} / \mathrm{TiO}_{2}$ photoelectrochemical systems.

As novel nanomaterials, semiconductor QDs are often used as sensitizers with narrow-bandgap semiconductors in PEC water splitting, owing to their many unique properties such as quantum size effects and multiple exciton generation [67-69]. Coupling the phenomena of quantum confinement and slow light can enhance light conversion efficiency to improve the performance of QD-sensitized wide band gap semiconductors [70]. Cheng et al. [71] reported an innovative electrode design by combining a $\mathrm{TiO}_{2}$ inverse opal with CdS QDs sensitizer for solar-light-driven hydrogen production. The 3D percolated periodic pore structure of the $\mathrm{TiO}_{2}$ inverse opal provided a high

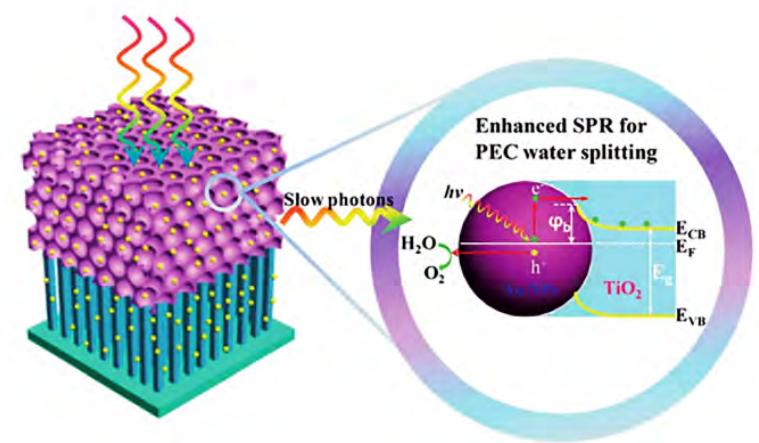

Fig. 4. Schematic diagram for the synergy of the slow photon effect of $\mathrm{TiO}_{2}$ photonic crystal and SPR enhanced PEC water splitting under light illumination. Reproduced with permission [66]. (Copyright 2014 Royal Society of Chemistry Publishing Group). surface area for QD loading, good electrical transport pathways, and intimate contact with the electrolyte. The QDs acted as "light antennas" greatly improving the visible-light harvesting, the type II band alignment with $\mathrm{TiO}_{2}$ also favored interfacial charge transfer and separation. Moreover, the slow photons facilitated photon-QD interactions, resulting in enhanced light absorption.

Among non- $\mathrm{TiO}_{2}$ photonic crystals, important materials for water splitting are photonic crystals of $\mathrm{BiVO}_{4}$, owing to a direct bandgap of $2.4 \mathrm{eV}$ and the appropriate valence band position for $\mathrm{O}_{2}$ evolution. Zhang and coworkers developed a photonic nano-architecture to improve charge carrier generation and separation by manipulating and confining light absorption in a visible-light-active photoanode constructed from a $\mathrm{BiVO}_{4}$ photonic crystal and plasmonic nanostructures [72]. Synergistic effects of the photonic crystal stop bands and plasmonic absorption were observed to operate in this photonic nanostructure. Within the scaffold of an inverse opal photonic crystal, the surface plasmon resonance is considerably enhanced by photonic Bragg resonance (Fig. 5). These nanophotonic photoanodes showed AM 1.5 photocurrent densities of $3.1 \pm 0.1$ $\mathrm{mA} / \mathrm{cm}^{2}$ at $1.23 \mathrm{~V}_{\mathrm{RHE}}$, which is among the highest reported for oxide-based photoanodes and over 4 times as high as that of an unstructured planar photoanode.

Nan et al. [73] fabricated carbon quantum dot (CQD) coated $\mathrm{BiVO}_{4}$ inverse opal (io- $\mathrm{BiVO}_{4}$ ) structures, which showed markedly improved PEC hydrogen generation. The io- $\mathrm{BiVO}_{4}$ maxim-

a

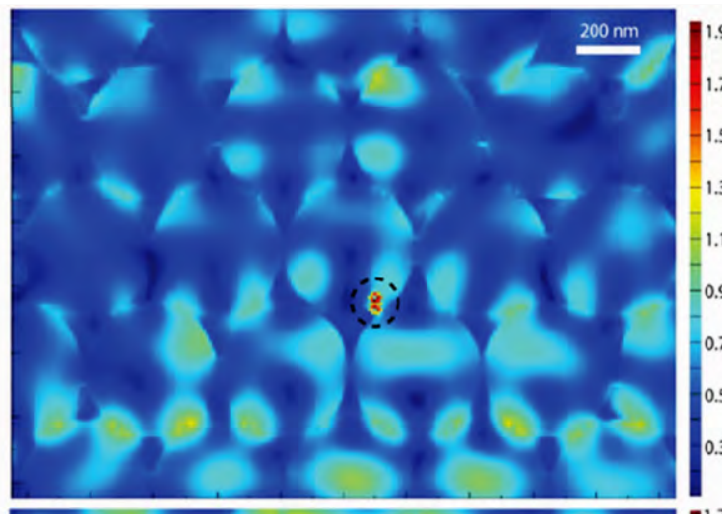

b

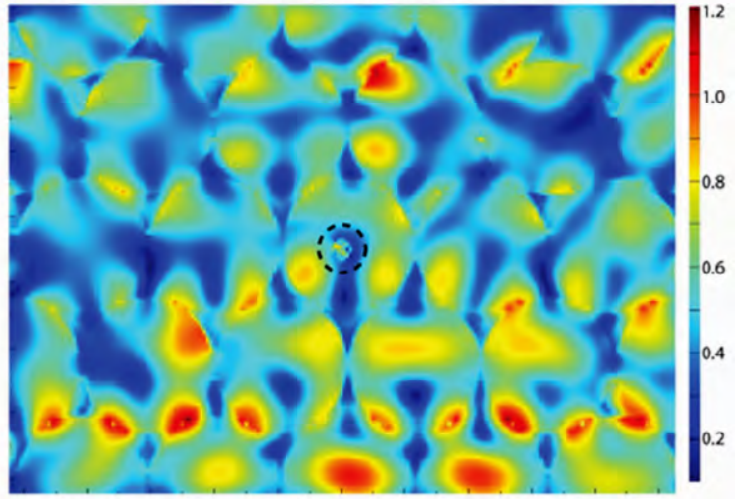

Fig. 5. Simulated electric field distribution for gold NP (in the black dashed circles) modified $\mathrm{BiVO}_{4}$ inverse opal at $\lambda=533 \mathrm{~nm}$. The $20-\mathrm{nm}$ gold NP is either (a) on the inverse opal wall, or (b) in the center of one of the pores in the inverse opal away from the wall. Reproduced with permission [72]. (Copyright 2014 Wiley-VCH Publishing Group). 
ized photon trapping through a slow light effect, while maintaining an adequate surface area for effective redox reactions. The CQDs were then incorporated into the io- $\mathrm{BiVO}_{4}$ to further improve the photoconversion efficiency. Owing to the strong visible light absorption properties of CQDs and the enhanced separation of the photoexcited electrons, the CQD coated io- $\mathrm{BiVO}_{4}$ exhibited a maximum photon-to-hydrogen conversion efficiency, which was 6 times as high as that of pure $\mathrm{BiVO}_{4}$ thin films.

Moreover, some photonic crystals used as photocatalysts to produce $\mathrm{H}_{2}$ through photocatalytic water splitting, where the slow photon effect has been observed to enhance $\mathrm{H}_{2}$ production efficiency, such as $\mathrm{TiO}_{2}$ NT-photonic crystals [59,74], $\mathrm{C} @ \mathrm{Cr}-\mathrm{SrTiO}_{3} / \mathrm{TiO}_{2} \quad$ NT-photonic crystals [75], F-doped $\mathrm{SnO}_{2} / \mathrm{TiO}_{2} / \mathrm{BiVO}_{4}$ [76], $\mathrm{SnO}_{2} / \mathrm{WO}_{3}[77,78]$, $\mathrm{TiO}_{2} /$ F-doped $\mathrm{SnO}_{2}$ [79], $\mathrm{TiO}_{2}-\mathrm{Au}-\mathrm{CdS}$ [80], and TaON [81].

\section{4. $\mathrm{CO}_{2}$ photoreduction}

Large amounts of anthropogenic $\mathrm{CO}_{2}$ emissions associated with increased fossil fuel consumption have led to global warming and an energy crisis. Photocatalytic reduction of $\mathrm{CO}_{2}$ into solar fuels such as methane or methanol is believed to be one of the best methods to address these two problems. In addition to light harvesting and charge separation, the adsorption/activation and reduction of $\mathrm{CO}_{2}$ at the surface of photocatalysts remains a critical challenge, which greatly limits overall photoconversion efficiency and the selectivity of $\mathrm{CO}_{2}$ reduction. This review describes recent advances in our fundamental understanding of $\mathrm{CO}_{2}$ photoreduction on photonic crystal and provides an overview for enhancing the light adsorption of photonic crystals.

Ren et al. prepared a $\mathrm{Cu} / \mathrm{TiO}_{2}$ inverse opal generated in-situ on optical fibers by sol-gel technology, which was shown to be effective for improving the photon utilization rate in a photocatalytic reactor [82]. The $\mathrm{TiO}_{2}$ inverse opal slowed photons and improved the quantum efficiency for photoreduction of gaseous $\mathrm{CO}_{2}$ to $\mathrm{CH}_{3} \mathrm{OH}$ in the presence of water vapor and UV light.

Wei et al. [83] prepared $\mathrm{Au} @ \mathrm{CdS} / \mathrm{IO}-\mathrm{TiO}_{2}$ photocatalysts that consisted of core-shell-structured Au@CdS NPs uniformly dispersed on $\mathrm{IO}^{-\mathrm{TiO}_{2}}$. The core-shell structured Au@CdS NPs with a CdS shell of adjustable thickness were dispersed on the inner walls of uniform macropores. The slow photon effect of the inverse opal structured $\mathrm{TiO}_{2}$ with moderate pore sizes improved the light-harvesting efficiency. The vectorial electron transfer $\left(\mathrm{TiO}_{2} \rightarrow \mathrm{Au} \rightarrow \mathrm{CdS}\right)$ of the all-solid-state Z-scheme system with a $\mathrm{CdS}$ (shell)-Au(core)- $\mathrm{TiO}_{2}$ (support) nanojunction was favorable for separation of photogenerated electrons and holes. Combined with the synergistic effects of the photonic crystals and vectorial electron transfer, Au@CdS/IO-TiO 2 catalysts exhibited superior photocatalytic performance for $\mathrm{CO}_{2}$ reduction to $\mathrm{CH}_{4}$ under simulated solar irradiation. The highest photocatalytic activity and selectivity for $\mathrm{CO}_{2}$ reduction were as follows: $\mathrm{CH}_{4}$ formation rate of $41.6 \mu \mathrm{mol} / \mathrm{g} \cdot \mathrm{h}$, and selectivity for $\mathrm{CH}_{4}$ production of $98.6 \%$. The formation rates of $\mathrm{H}_{2}, \mathrm{CO}, \mathrm{O}_{2}$ were $18.2,0.6$, and $109.5 \mu \mathrm{mol} / \mathrm{g} \cdot \mathrm{h}$, respectively. The highest formation rate of $\mathrm{O}_{2}(109.5 \mu \mathrm{mol} / \mathrm{g} \cdot \mathrm{h})$, was larger than the stoichiometric theoretical amount $(92.6 \mu \mathrm{mol} / \mathrm{g} \cdot \mathrm{h})$ calculated by the formation rates of $\mathrm{CH}_{4}, \mathrm{H}_{2}$ and $\mathrm{CO}$, which suggests that some others hydrocarbon products may be produced but were undetected.

Additionally, Jiao et al. prepared a series of novel photocatalysts via the colloidal crystal template method, including $\mathrm{AuPd} / \mathrm{TiO}_{2}$ (Fig. 6) [84], $\mathrm{CeO}_{2} / \mathrm{TiO}_{2}$ [85], and $\mathrm{Au} / \mathrm{TiO}_{2}$ [86]. In these catalysts, $3 \mathrm{D}$ ordered macroporous $\left(3 \mathrm{DOM} \mathrm{TiO}_{2}\right)$ as the support decorated with $\mathrm{AuPd} \mathrm{NPs}, \mathrm{CeO}_{2}$ nanolayers and $\mathrm{Au}$ NPs, which were homogeneously dispersed on the inner wall of the 3DOM $\mathrm{TiO}_{2}$. They exhibited excellent photocatalytic activity for $\mathrm{CO}_{2}$ reduction by gas bubbling-assisted membrane reduction method. The enhanced photocatalytic activity might originate from the excellent light-harvesting capacity and separation efficiency of photogenerated electrons and holes. The light-harvesting efficiency was improved by the slow photon effect of the 3DOM structured $\mathrm{TiO}_{2}$ and the heterojunction between the $\mathrm{TiO}_{2}$ with the AuPd NPs, $\mathrm{CeO}_{2}$ nanolayers and $\mathrm{Au}$ NPs. Moreover, the Au NPs deposited on the $\mathrm{TiO}_{2}$ surface could absorb more visible light and induce a stronger SPR effect on the $\mathrm{Au}$ NPs for excitation of electrons to $\mathrm{TiO}_{2}$ to reduce $\mathrm{CO}_{2}$ into $\mathrm{CH}_{4}$.

Jiao et al. prepared a series of $\mathrm{Pt} / \mathrm{TiO}_{2}$ photonic crystal photocatalysts with a well-defined inverse opal structure, and Pt NPs with uniform sizes (approximately $2.5 \mathrm{~nm}$ ) homogeneously dispersed on the inner wall of carriers [87]. The Pt/TiO photonic crystal catalysts exhibited super catalytic activity for the reduction of $\mathrm{CO}_{2}$ and $\mathrm{H}_{2} \mathrm{O}$, which was attributed to the slow photon effect of the inverse opal structure with moderate pore sizes, and the Pt NPs acting as electron trapping centers to improve charge separation of photoexcited $\mathrm{TiO}_{2}$, as well as strong absorption of visible light and adsorption of $\mathrm{CO}_{2}$ molecules induced by oxygen vacancies.

For the photonic crystal catalysts described above, $\mathrm{CO}_{2}$ photoreduction was achieved in a $\mathrm{CO}_{2}-\mathrm{H}_{2} \mathrm{O}$ atmosphere via a gas bubbling-assisted method. The $\mathrm{CO}_{2}$ gas flows through a water vapor generator (bubbler) and then into the reactor, with photonic crystals as the catalyst in the reactor. In the reaction of $\mathrm{CO}_{2}$ by photoreduction with $\mathrm{H}_{2} \mathrm{O}$ vapor, $\mathrm{CH}_{3} \mathrm{OH}, \mathrm{CH}_{4}, \mathrm{CO}$, $\mathrm{H}_{2}$, and $\mathrm{O}_{2}$ were produced by $\mathrm{CO}_{2}$ reduction and $\mathrm{H}_{2} \mathrm{O}$ oxidation. $\mathrm{CO}_{2}$ is reduced in the presence of water owing to the properties of photocatalysts. $\mathrm{TiO}_{2}$ photonic crystals act as a support modi-

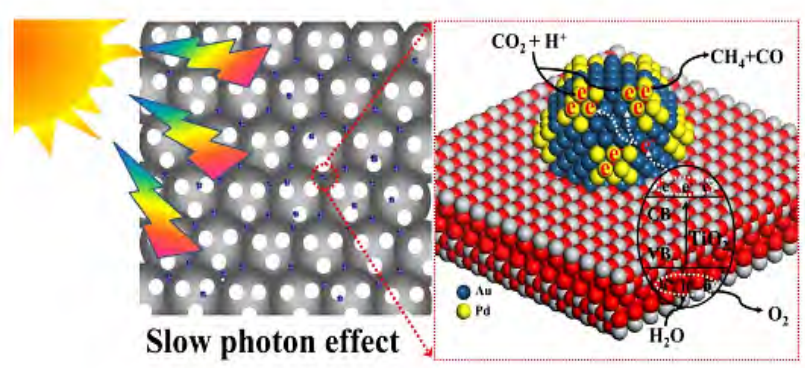

Fig. 6. Catalytic mechanism for the photoreduction of $\mathrm{CO}_{2}$ with $\mathrm{H}_{2} \mathrm{O}$ over AuPd/3DOM-TiO 2 catalyst. Reproduced with permission [84]. (Copyright 2017 Elsevier Publishing Group). 
Table 1

Main products and enhancement factor for solar-to-fuel conversion over various photonic crystals.

\begin{tabular}{|c|c|c|c|c|}
\hline Photocatalysts (photonic crystal) & Reaction & Major Products & Enhancement factor & Ref. \\
\hline $\mathrm{Pt}_{-\mathrm{TiO}_{2}}$ & $\mathrm{H}_{2}$ generation in formate buffer & $\mathrm{H}_{2}$ & 2 times & 40 \\
\hline Pt- $\mathrm{TiO}_{2}$ & $\mathrm{H}_{2}$ generation in methanol aqueous solution & $\mathrm{H}_{2}$ & 2.5 times & 42 \\
\hline $\mathrm{Au} / \mathrm{TiO}_{2}$ & $\mathrm{H}_{2}$ generation in ethanol aqueous solution & $\mathrm{H}_{2}$ & 2.5 times & 56 \\
\hline $\mathrm{CdS} / \mathrm{ZrO}_{2}$ & $\mathrm{H}_{2}$ generation in $\mathrm{Na}_{2} \mathrm{~S}$ and $\mathrm{Na}_{2} \mathrm{SO}_{3}$ aqueous solution & $\mathrm{H}_{2}$ & 4.7 times & 57 \\
\hline $\mathrm{CdS}-\mathrm{Au}-\mathrm{TiO}_{2}$ & $\mathrm{H}_{2}$ generation in $\mathrm{Na}_{2} \mathrm{~S}$ and $\mathrm{Na}_{2} \mathrm{SO}_{3}$ aqueous solution & $\mathrm{H}_{2}$ & 5.5 times & 41 \\
\hline $\mathrm{g}-\mathrm{C}_{3} \mathrm{~N}_{4}$ & $\mathrm{H}_{2}$ generation in triethanolamine aqueous solution & $\mathrm{H}_{2}$ & 8.82 times & 43 \\
\hline $\mathrm{TiO}_{2} \mathrm{NTPC}$ & $\mathrm{PEC}$ in $\mathrm{KOH}$ aqueous solution & $\mathrm{H}_{2}$ & $50 \%$ & 61 \\
\hline $\mathrm{WO}_{3}$ & PEC in $\mathrm{Na}_{2} \mathrm{SO}_{4}$ aqueous solution & $\mathrm{H}_{2}$ & 2.5 times & 62 \\
\hline $\mathrm{WO}_{3} / \mathrm{BiVO}_{4} / \mathrm{Co}-\mathrm{Pi}$ & PEC in $\mathrm{Na}_{2} \mathrm{SO}_{4}$ aqueous solution & $\mathrm{H}_{2}$ & 2.5 times & 63 \\
\hline $\mathrm{Bi}_{2} \mathrm{WO}_{6}$ & PEC in $\mathrm{Na}_{2} \mathrm{SO}_{4}$ aqueous solution & $\mathrm{H}_{2}$ & 3 times & 64 \\
\hline $\mathrm{Au} / \mathrm{TiO}_{2} \mathrm{NTPC}$ & $\mathrm{PEC}$ in $\mathrm{KOH}$ aqueous solution & $\mathrm{H}_{2}$ & 2.25 times & 65 \\
\hline $\mathrm{Au} / \mathrm{TiO}_{2}$ & $\mathrm{PEC}$ in $\mathrm{KOH}$ aqueous solution & $\mathrm{H}_{2}$ & 2.4 times & 66 \\
\hline $\mathrm{CdS} / \mathrm{TiO}_{2}$ & PEC in $\mathrm{Na}_{2} \mathrm{~S}$ and $\mathrm{Na}_{2} \mathrm{SO}_{3}$ aqueous solution & $\mathrm{H}_{2}$ & 200 times & 71 \\
\hline $\mathrm{Mo}: \mathrm{BiVO}_{4} / \mathrm{Au}$ & PEC in phosphate aqueous solution & $\mathrm{H}_{2}$ & 4 times & 72 \\
\hline $\mathrm{C} / \mathrm{BiVO}_{4}$ & PEC in $\mathrm{Na}_{2} \mathrm{SO}_{4}$ aqueous solution & $\mathrm{H}_{2}$ & 6 times & 73 \\
\hline $\mathrm{P}-\mathrm{TiO}_{2} \mathrm{NTPC}$ & $\mathrm{PEC}$ in $\mathrm{NaOH}$ aqueous solution & $\mathrm{H}_{2}$ & 2.4 times & 59 \\
\hline $\mathrm{Ti}^{-\mathrm{TiO}_{2}} \mathrm{NTPC}$ & PEC in $\mathrm{KOH}$ aqueous solution & $\mathrm{H}_{2}$ & 10 times & 74 \\
\hline $\mathrm{C} @ \mathrm{Cr}-\mathrm{SrTiO}_{3} / \mathrm{TiO}_{2} \mathrm{NTPC}$ & $\mathrm{PEC}$ in $\mathrm{KOH}$ aqueous solution containing glucose & $\mathrm{H}_{2}$ & 4.4 times & 75 \\
\hline F-doped $\mathrm{SnO}_{2} / \mathrm{TiO}_{2} / \mathrm{BiVO}_{4}$ & $\mathrm{PEC}$ in $\mathrm{Na}_{2} \mathrm{SO}_{4}$ aqueous solution & $\mathrm{H}_{2}$ & 10 times & 76 \\
\hline F-Doped $\mathrm{SnO}_{2} / \mathrm{WO}_{3}$ & $\mathrm{PEC}$ in $\mathrm{Na}_{2} \mathrm{SO}_{4}$ and $\mathrm{Na}_{2} \mathrm{SO}_{3}$ aqueous solution & $\mathrm{H}_{2}$ & 6.4 times & 77 \\
\hline $\mathrm{SnO}_{2} / \mathrm{WO}_{3}$ & $\mathrm{PEC}$ in $\mathrm{Na}_{2} \mathrm{SO}_{4}$ aqueous solution & $\mathrm{H}_{2}$ & 6 times & 78 \\
\hline $\mathrm{TiO}_{2} /$ F-doped $\mathrm{SnO}_{2}$ & $\mathrm{PEC}$ in $\mathrm{KOH}$ aqueous solution & $\mathrm{H}_{2}$ & 11 times & 79 \\
\hline $\mathrm{TiO}_{2}-\mathrm{Au}-\mathrm{CdS}$ & $\mathrm{H}_{2}$ generation in $\mathrm{Na}_{2} \mathrm{~S}$ and $\mathrm{Na}_{2} \mathrm{SO}_{3}$ aqueous solution & $\mathrm{H}_{2}$ & $31 \%$ & 80 \\
\hline $\mathrm{TaON}$ & $\mathrm{H}_{2}$ generation in ethanol aqueous solution & $\mathrm{H}_{2}$ & 7 times & 81 \\
\hline $\mathrm{Cu} / \mathrm{TiO}_{2}$ & $\mathrm{CO}_{2}$ photoreduction in $\mathrm{CO}_{2}-\mathrm{H}_{2} \mathrm{O}$ atmosphere & $\mathrm{CH}_{3} \mathrm{OH}$ & 13.5 times & 82 \\
\hline $\mathrm{Au} @ \mathrm{CdS} / \mathrm{TiO}_{2}$ & $\mathrm{CO}_{2}$ photoreduction in $\mathrm{CO}_{2}-\mathrm{H}_{2} \mathrm{O}$ atmosphere & $\mathrm{H}_{2}: \mathrm{CH}_{4}(1: 2.3)$ & 2.7 times & 83 \\
\hline $\mathrm{AuPd} / \mathrm{TiO}_{2}$ & $\mathrm{CO}_{2}$ photoreduction in $\mathrm{CO}_{2}-\mathrm{H}_{2} \mathrm{O}$ atmosphere & $\mathrm{H}_{2}: \mathrm{CH}_{4}(1: 1)$ & 11 times & 84 \\
\hline $\mathrm{CeO}_{2} / \mathrm{TiO}_{2}$ & $\mathrm{CO}_{2}$ photoreduction in $\mathrm{CO}_{2}-\mathrm{H}_{2} \mathrm{O}$ atmosphere & $\mathrm{CO}$ & 2 times & 85 \\
\hline $\mathrm{Au} / \mathrm{TiO}_{2}$ & $\mathrm{CO}_{2}$ photoreduction in $\mathrm{CO}_{2}-\mathrm{H}_{2} \mathrm{O}$ atmosphere & $\mathrm{CH}_{4}$ & 2 times & 86 \\
\hline $\mathrm{Pt} / \mathrm{TiO}_{2}$ & $\mathrm{CO}_{2}$ photoreduction in $\mathrm{CO}_{2}-\mathrm{H}_{2} \mathrm{O}$ atmosphere & $\mathrm{H}_{2}: \mathrm{CH}_{4}(10: 1)$ & 2.4 times & 87 \\
\hline
\end{tabular}

fied with $\mathrm{Cu}, \mathrm{Au} @ \mathrm{CdS}, \mathrm{AuPd}, \mathrm{CeO}_{2}, \mathrm{Au}$, and Pt, and these modifications showed considerable effects on the catalytic efficiency and selectivity. For example, $\mathrm{Cu}$ showed a high sensitivity for $\mathrm{CH}_{3} \mathrm{OH}, \mathrm{Au}$ for $\mathrm{CH}_{4}$, and $\mathrm{Pt}$ for $\mathrm{H}_{2} . \mathrm{CO}_{2}$ and $\mathrm{H}_{2} \mathrm{O}$ were reduced and water acted as a hole receptor being oxidized to produce $\mathrm{O}_{2}$. No water oxidation catalysts or sacrificial reagents were used in the works described in this review. The amount of $\mathrm{O}_{2}$ produced corresponded with the theoretical amount calculated from the hydrogen and hydrocarbon products obtained from the $\mathrm{CO}_{2}$ and $\mathrm{H}_{2} \mathrm{O}$ reduction.

\section{Conclusions and perspectives}

To date, considerable achievements have been made in the design and fabrication of photonic crystal photocatalysts for efficient photocatalytic $\mathrm{H}_{2}$ production and $\mathrm{CO}_{2}$ reduction. Photonic crystals show great promise for improving solar-to-fuel conversion efficiencies through the slow photon effect, which has tremendous benefits for light harvesting. To enhance the slow photon effect, the photonic crystal stop band is tuned to the semiconductor band edge or the excitation maxima of the sensitizer (e.g., QDs, plasmonic metal NPs). The slow-photon effect in light-harvesting enhancement and its exploitation in photocatalytic $\mathrm{H}_{2}$ production and $\mathrm{CO}_{2}$ reduction may provide insights into the rational design and fabrication of photocatalytic systems for solar-to-fuel energy conversion.

Although in most cases photocatalytic activities can be enhanced by forming photonic crystals, actual solar-to-fuel conversion efficiencies are still a long way from meeting criteria for commercialization. This is because of the limitations of semiconductor photocatalysts such as the high overpotentials required for $\mathrm{H}_{2} / \mathrm{O}_{2}$ evolution and the very low activity for red-photons and near-IR light. Furthermore, long-term stability is a serious problem of photonic crystal structures and remains an important issue in the design and fabrication of photonic crystal photocatalysts in the future for achieving satisfactory efficiency in solar-to-fuel energy conversion.

\section{References}

[1] D. W. Hawes, D. Feldman, D. Banu, Energy Buildings, 1993, 20, 77-86.

[2] T. Kodama, Progr. Energy Combust., 2003, 29, 567-597.

[3] B. Azzopardi, C. J. M. Emmott, A. Urbina, F. C. Krebs, J. Mutale, J. Nelson, Energy Environ. Sci., 2011, 4, 3741-3753.

[4] H. B. Gray, A. W. Maverick, Science, 1981, 214, 1201-1205.

[5] A. Fujishima, K. Honda, Nature, 1972, 238, 37-38. 


\section{Graphical Abstract}

Chin. J. Catal., 2018, 39: 379-389 doi: 10.1016/S1872-2067(17)62930-9

\section{Slow photons for solar fuels \\ Xiuzhen Zheng, Yang Yang, Shifu Chen *, Liwu Zhang * \\ Fudan university; Huaibei Normal University}

This article reviews recent developments in the applications of photonic crystals to photocatalytic $\mathrm{H}_{2}$ production and $\mathrm{CO}_{2}$ reduction based on slow photons, highlighting promising approaches towards improving light harvesting in solar-energy-conversion technologies.

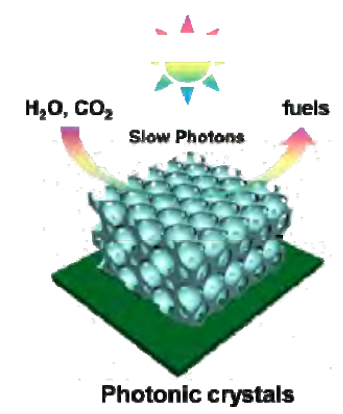

109, 6334-6342.

[6] M. Halmann, Nature, 1978, 275, 115-116.

[7] Y. P. Yuan, L. W. Ruan, J. Barber, S. C. Joachim Loo, C. Xue, Energy Environ. Sci., 2014, 7, 3934-3951.

[8] X. X. Chang, T. Wang, J. L. Gong, Energy Environ. Sci., 2016, 9, 2177-2196.

[9] Y. W. Zhang, J. H. Liu, G. Wu, W. Chen, Nanoscale, 2012, 4, 5300-5303.

[10] Y. Li, T. Kunitake, S. Fujikawa, J. Phys. Chem. B, 2006, 110, 13000-13004.

[11] A. Usami, Sol. Energy Mater. Sol. C, 2000, 64, 73-83.

[12] S. Hore, P. Nitz, C. Vetter, C. Prahl, M. Niggemann, R. Kern, Chem. Commun., 2005, 15, 2011-2013.

[13] M. H. Sun, S. Z. Huang, L. H. Chen, Y. Li, X. Y. Yang, Z. Y. Yuan, B. L. Su, Chem. Soc. Rev., 2016, 45, 3479-3563.

[14] J. Liu, H. Zhao, M. Wu, B. Van der Schueren, Y. Li, O. Deparis, J. Ye, G. A. Ozin, T. Hasan, B. L. Su, Adv. Mater., 2017, 29, 1605349.

[15] S. Lou, X. M. Guo, T. X. Fan, D. Zhang, Energy Environ. Sci., 2012, 5, 9195-9216.

[16] F. Sordello, V. Maurino, C. Minero, Molecular PhotochemistryVarious Aspects, Intech Open Access Publisher, 2012, 63-86.

[17] X. Z. Zheng, L. W. Zhang, Energy Environ. Sci., 2016, 9, 2511-2532.

[18] J. J. Pietron, P. A. DeSario, J. Photon. Energy, 2017, 7, 012007/1-012007/12.

[19] E. Chow, S. Y. Lin, S. G. Johnson, P. R. Villeneuve, J. D. Joannopoulos, J. R. Wendt, G. A. Vawter, W. Zubrzycki, H. Hou, A. Alleman, Nature, 2000, 407, 983-986.

[20] J. I. L. Chen, G. von Freymann, V. Kitaev, G. A. Ozin, J. Am. Chem. Soc., 2007, 129, 1196-1202.

[21] X. Z. Zheng, D. Z. Li, X. F. Li, L. H. Yu, P. Wang, X. Y. Zhang, J. L. Fang, Y. Shao, Y. Zheng, Phys. Chem. Chem. Phys., 2014, 16, 15299-15306.

[22] S. Bayram, L. Halaoui, Part. Part. Syst. Char., 2013, 30, 706-714.

[23] S. Nishimura, N. Abrams, B. A. Lewis, L. I. Halaoui, T. E. Mallouk, K. D. Benkstein, J. van de Lagemaat, A. J. Frank, J. Am. Chem. Soc., 2003, 125, 6306-6310.

[24] G. Collins, D. McNulty, S. O'Hanlon, H. Geaney, E. Armstrong, C. O'Dwyer, Sci. Technol. Adv. Mat., 2016, 17, 563-582.

[25] M. Wu, J. Jin, J. Liu, Z. Deng, Y. Li, O. Deparis, B. L. Su, J. Mater. Chem. $A, \mathbf{2 0 1 3}, 1,15491-15500$.

[26] Q. S. Peng, H. Y. Zhao, L. Qian, Y. B. Wang, G. H. Zhao, Appl. Catal. B, 2015, 174, 157-166.

[27] J. Liu, M. Z. Li, J. X. Wang, Y. L. Song, L. Jiang, T. Murakami, A. Fujishima, Environ. Sci. Technol., 2009, 43, 9425-9431.

[28] L. I. Halaoui, N. M. Abrams, T. E. Mallouk, J. Phys. Chem. B, 2005,
29] N. Yantara, T. T. T. Pham, P. P. Boix, N. Mathews, Phys. Chem. Chem. Phys., 2015, 17, 21694-21701.

[30] T. Suezaki, H. Yano, T. Hatayama, G. A. Ozin, T. Fuyuki, Appl. Phys. Lett., 2011, 98, 072106.

[31] W. Xue, Y. Yu, L. Ottaviano, Y. Chen, E. Semenova, K. Yvind, J. Mork, Phys. Rev. Lett., 2016, 116, 063901/1-063901/5.

[32] F. Bordas, C. Seassal, E. Dupuy, P. Regreny, M. Gendry, P. Viktorovich, M. J. Steel, A. Rahmani, Opt. Express, 2009, 17, 5439-5445.

[33] S. Gardin, F. Bordas, X. Letartre, C. Seassal, A. Rahmani, R. Bozio, P. Viktorovitch, Opt. Express, 2008, 16, 6331-6339.

[34] M. X. Xing, W. H. Zheng, W. J. Zhou, W. Chen, A. J. Liu, H. L. Wang, Chin. Phys. Lett., 2010, 27, 024213/1-024213/4.

[35] T. Baba, T. Kawasaki, H. Sasaki, J. Adachi, D. Mori, Opt. Express, 2008, 16, 9245-9253.

[36] K. Abedi, S. M. Mirjalili, Opt. Commun., 2015, 339, 7-13.

[37] P. Agruzov, A. Shamray, M. Ocequeda Miramontes, E. H. Hernandez, S. Stepanov, Appl. Phys. B, 2012, 108, 827-832.

[38] J. T. Li, L. O'Faolain, T. F. Krauss, Opt. Express, 2012, 20,

[39] D. L. Wang, Z. Y. Yu, Y. M. Liu, X. T. Guo, S. A. Zhou, J. Optics, 2012, 14, 125101.

[40] F. Sordello, C. Minero, Appl. Catal. B, 2015, 163, 452-458.

[41] X. F. Cui, Y. J. Wang, G. Y. Jiang, Z. Zhao, C. Y. Xu, Y. C. Wei, A. J. Duan, J. Liu, J. S. Gao, RSC Adv., 2014, 4, 15689-15694.

[42] J. Liu, G. L. Liu, M. Z. Li, W. Z. Shen, Z. Y. Liu, J. X. Wang, J. C. Zhao, L. Jiang, Y. L. Song, Energy Environ. Sci., 2010, 3, 1503-1506.

[43] L. Sun, M. J. Yang, J. F. Huang, D. S. Yu, W. Hong, X. D. Chen, Adv. Funct. Mater., 2016, 26, 4943-4950.

[44] K. Kim, P. Thiyagarajan, H. J. Ahn, S. I. Kim, J. H. Jang, Nanoscale, 2013, 5, 6254-6260.

[45] M. Balamurugan, G. Yun, K. S. Ahn, S. H. Kang, J. Phys. Chem. C, 2017, 121, 7625-7634.

[46] L. W. Zhang, E. Reisner, J. J. Baumberg, Energy Environ. Sci., 2014, 7, 1402-1408.

[47] R. Boppella, S. T. Kochuveedu, H. Kim, M. J. Jeong, F. M. Mota, J. H. Park, D. H. Kim, ACS Appl. Mater. Interfaces, 2017, 9, 7075-7083.

[48] M. Zhou, J. Bao, Y. Xu, J. J. Zhang, J. F. Xie, M. L. Guan, C. L. Wang, L. Y. Wen, Y. Lei, Y. Xie, ACS Nano, 2014, 8, 7088-7098.

[49] X. J. Shi, K. Zhang, K. Shin, J. H. Moon, T. W. Lee, J. H. Park, Phys. Chem. Chem. Phys., 2013, 15, 11717-11722.

[50] K. Zhang, X. J. Shi, J. K. Kim, J. S. Lee, J. H. Park, Nanoscale, 2013, 5, 1939-1944. 17474-17479. 
[51] Y. R. Lu, P. F. Yin, J. Mao, M. J. Ning, Y. Z. Zhou, C. K. Dong, T. Ling, X. W. Du, J. Mater. Chem. A, 2015, 3, 18521-18527.

[52] M. Ren, R. Ravikrishna, K. T. Valsaraj, Environ. Sci. Technol., 2006, 40, 7029-7033.

[53] J. I. L. Chen, G. von Freymann, S. Y. Choi, V. Kitaev, G. A. Ozin, Adv. Mater., 2006, 18, 1915-1919.

[54] S. L. Chen, A. J. Wang, C. T. Hu, C. Dai, J. B. Benziger, AICHE J., 2012, $58,568-572$.

[55] F. Sordello, C. Duca, V. Maurino, C. Minero, Chem. Commun., 2011, 47, 6147-6149.

[56] G. I. N. Waterhouse, A. K. Wahab, M. Al-Oufi, V. Jovic, D. H. Anjum, D. Sun-Waterhouse, J. Llorca, H. Idriss, Sci. Rep., 2013, 3, 2849.

[57] R. Mitchell, R. Brydson, R. E. Douthwaite, Phys. Chem. Chem. Phys., 2015, 17, 493-499.

[58] Z. Geng, Y. Zhang, X. Yuan, M. X. Huo, Y. H. Zhao, Y. Lu, Y. Qiu, J. Alloy. Compd., 2015, 644, 734-741.

[59] Z. Z. Li, Y. M. Xin, W. L. Wu, B. H. Fu, Z. H. Zhang, ACS Appl. Mater. Interfaces., 2016, 8, 30972-30979.

[60] Z. Y. Wu, J. Wang, Z. Y. Zhou, G. H. Zhao, J. Mater. Chem. A, 2017, 5, 12407-12415.

[61] G. L. Chiarello, A. Zuliani, D. Ceresoli, R. Martinazzo, E. Selli, ACS Catal., 2016, 6, 1345-1353.

[62] X. Q. Chen, J. H. Ye, S. X. Ouyang, T. Kako, Z. S. Li, Z. G. Zou, ACS Nano, 2011, 5, 4310-4318.

[63] H. F. Zhang, W. W. Zhou, Y. P. Yang, C. W. Cheng, Small, 2017, 13,1603840 .

[64] L. W. Zhang, C. Baumanis, L. Robben, T. Kandiel, D. Bahnemann, Small, 2011, 7, 2714-2720.

[65] Z. H. Zhang, L. B. Zhang, M. N. Hedhili, H. N. Zhang, P. Wang, Nano Lett., 2013, 13, 14-20.

[66] X. Zhang, Y. Liu, S. T. Lee, S. H. Yang, Z. H. Kang, Energy Environ. Sci., 2014, 7, 1409-1419.

[67] F. L. Su, J. W. Lu, Y. Tian, X. B. Ma, J. L. Gong, Phys. Chem. Chem. Phys., 2013, 15, 12026-12032.

[68] L. Ge, F. Zuo, J. K. Liu, Q. Ma, C. Wang, D. Z. Sun, L. Bartels, P. Y. Feng, J. Phys. Chem. C, 2012, 116, 13708-13714.

[69] H. M. Chen, C. K. Chen, Y. C. Chang, C. W. Tsai, R. S. Liu, S. F. Hu, W.
S. Chang, K. H. Chen, Angew. Chem. Int. Ed., 2010, 49, 5966-5969.

[70] M. El Harakeh, L. Halaoui, J. Phys. Chem. C, 2010, 114, 2806-2813.

[71] C. W. Cheng, S. K. Karuturi, L. J. Liu, J. P. Liu, H. X. Li, L. T. Su, A. I. Y. Tok, H. J. Fan, Small, 2012, 8, 37-42.

[72] L. W. Zhang, C. Y. Lin, V. K. Valev, E. Reisner, U. Steiner, J. J. Baumberg, Small, 2014, 10, 3970-3978.

[73] F. Nan, Z. H. Kang, J. L. Wang, M. R. Shen, L. Fang, Appl. Phys. Lett., 2015, 106, 153901/1-153901/5.

[74] Z. H. Zhang, X. L. Yang, M. N. Hedhili, E. Ahmed, L. Shi, P. Wang, ACS Appl. Mater. Interfaces, 2014, 6, 691-696.

[75] Y. J. Zhang, B. Tang, Z. Y. Wu, H. J. Shi, Y. Zhang, G. H. Zhao, Green Chem., 2016, 18, 2424-2434.

[76] H. F. Zhang, C. W. Cheng, ACS Energy Lett., 2017, 2, 813-821.

[77] S. Y. Cho, S. H. Kang, G. Yun, M. Balamurugan, K. S. Ahn, J. Korean Phys. Soc., 2017, 70, 162-168.

[78] G. Yun, M. Balarmurugan, H. S. Kim, K. S. Ahn, S. H. Kang, J. Phys. Chem. C, 2016, 120, 5906-5915.

[79] Y. Gun, G. Y. Song, V. H. V. Quy, J. Heo, H. Lee, K. S. Ahn, S. H. Kang, ACS Appl. Mater. Interfaces, 2015, 7, 20292-20303.

[80] H. Zhao, M. Wu, J. Liu, Z. Deng, Y. Li, B. L. Su, Appl. Catal. B, 2016, 184, 182-190.

[81] M. Y. Tsang, N. E. Pridmore, L. J. Gillie, Y. H. Chou, R. Brydson, R. E. Douthwaite, Adv. Mater., 2012, 24, 3406-3409.

[82] M. M. Ren, K. Valsaraj, Int. J. Chem. React. Eng., 2009, 7(1) DOI: 10.2202/1542-6580.2056

[83] Y. C. Wei, J. Q. Jiao, Z. Zhao, J. Liu, J. M. Li, G. Y. Jiang, Y. J. Wang, A. J. Duan, Appl. Catal. B, 2015, 179, 422-432.

[84] J. Q. Jiao, Y. C. Wei, Y. L. Zhao, Z. Zhao, A. J. Duan, J. Liu, Y. Y. Pang, J. M. Li, G. Y. Jiang, Y. J. Wang, Appl. Catal. B, 2017, 209, 228-239.

[85] J. Q. Jiao, Y. C. Wei, Z. Zhao, J. Liu, J. M. Li, A. J. Duan, G. Y. Jiang, Ind. Eng. Chem. Res., 2014, 53, 17345-17354.

[86] J. Q. Jiao, Y. C. Wei, Z. Zhao, W. J. Zhong, J. Liu, J. M. Li, A. J. Duan, G. Y. Jiang, Catal. Today, 2015, 258, 319-326.

[87] J. Q. Jiao, Y. C. Wei, K. B. Chi, Z. Zhao, A. J. Duan, J. Liu, G. Y. Jiang, Y. J. Wang, X. L. Wang, C. C. Han, P. Zheng, Energy Technol., 2017, 5, 877-883.

\title{
慢光子效应在太阳能转换燃料中的应用
}

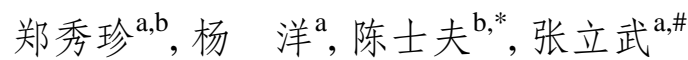 \\ a复旦大学大气污染防治重点实验室, 环境科学与工程系, 上海 200433 \\ b淮北师范大学化学与材料科学学院, 安徽淮北 235000
}

摘要: 随着全球性能源短缺和环境恶化问题的日益突出, 能源和环境问题已成为目前人类面临和亟待解决的重大难题, 研 究新的替代能源和清洁环境技术备受关注. 世界各国的科研工作者都在积极探索和寻找有效的对策, 其中通过光催化分 解水和还原 $\mathrm{CO}_{2}$ 将太阳能转化为有价值的氢气和碳氢燃料可有效缓解人类对可再生能源和清洁能源的需求. 然而, 现有催 化剂的转换效率还达不到商业化的要求, 主要原因是太阳光的利用率低和光生电荷的复合率高. 将催化剂构造成三维有 序孔状的光子晶体结构, 可有效提高催化剂对光的利用率.

光子晶体是一种特殊的周期性介电物质有序排列而成的微结构材料, 它对光有着特殊的调控作用, 可以通过光反射、 光散射和慢光子效应来调控光在材料介质结构中的传播和光与介质的相互作用. 三维反蛋白石结构的光子晶体不仅有光 子晶体的特征还具有本身特有的结构效应, 主要体现在以下两个方面: (1)光子晶体结构: 光子晶体具有内部相互连接的三 维框架结构和相互连通的球形孔道, 三维框架结构提供大的比表面积, 而有序的球形孔道有利于反应物分子的动态扩散; (2)光子晶体效应: 当光波长落在光子禁带范围内, 此波长的光将会被反射而不能在材料内传播; 当光子晶体材料内有缺陷 时可以发生多重散射, 增加光的利用率; 当光波长落在光子禁带红边的时候, 这部分的光将会“慢下来”并且作用光子晶体 的高介电物质部分; 当光波长落在光子禁带蓝边的时候, 这部分光也会“慢下来”并且作用于光子晶体的低介电物质部分. 通过调控光子禁带的位置, 可以得到不同波长的慢光子和调控作用于不同的材料物质上, 增强入射光的利用率和光与材料 
的相互作用.

基于光子晶体半导体材料既有电子能带又有光子能带的特点, 利用光的反射、散射和慢光子效应来调控光在光子晶体 中的传播, 能显著增强光与催化剂的相互作用. 尤其是光子禁带附近产生的慢光子效应对光有着特殊的调控作用, 可以减 慢一些特定频率的入射光在催化剂中的传输, 促进催化剂对光的吸收. 同时, 慢光子效应还能促进光生电子-空穴对的分 离, 提高光解水产氢和光化学还原 $\mathrm{CO}_{2}$ 的活性. 本文总结了光子晶体的慢光子效应促进光催化产 $\mathrm{H}_{2}$ 和 $\mathrm{CO}_{2}$ 还原的最新发展, 并研究了慢光子效应在太阳能转换为燃料中的作用. 基于慢光子效应对光的特殊调控作用, 构造具有光子晶体结构的催 化剂对促进太阳光的吸收和提高太阳能转换为燃料的效率具有重要的意义.

关键词: 光子晶体; 慢光子; 反蛋白石; 光解水; 产氢; 光还原 $\mathrm{CO}_{2}$

收稿日期: 2017-08-01. 接受日期: 2017-09-14. 出版日期: 2018-03-05.

*通讯联系人. 电子信箱: chshifu@chnu.edu.cn

\#通讯联系人. 电子信箱: zhanglw@fudan.edu.cn

基金来源：国家自然科学基金(21607027, 21507011, 21677037); 科技部项目(2016YFE0112200).

本文的电子版全文由Elsevier出版社在ScienceDirect上出版(http://www.sciencedirect.com/science/journal/18722067). 